ZOOLOGIA 32 (1): 23-32, February 2015

http://dx.doi.org/10.1590/S1984-46702015000100004

\title{
Occurrence and morphometrics of the brachioradialis muscle in wild carnivorans (Carnivora: Caniformia, Feliformia)
}

\author{
Paulo de Souza Junior ${ }^{1,4}$, Lucas M.R.P. dos Santos ${ }^{1}$, Daniele M.P. Nogueira1, \\ Marcelo Abidu-Figueiredo ${ }^{2} \&$ André L.Q. Santos ${ }^{3}$
}

\author{
'Laboratório de Anatomia Animal, Universidade Federal do Pampa. Rodovia BR-472, km 585, Caixa postal 118, \\ 97500-970 Uruguaiana, RS, Brazil. \\ ${ }^{2}$ Departamento de Biologia Animal, Universidade Federal Rural do Rio de Janeiro. Rodovia BR-465, km 07, \\ 23890-000 Seropédica, RJ, Brazil. \\ ${ }^{3}$ Laboratório de Ensino e Pesquisa em Animais Silvestres, Universidade Federal de Uberlândia. Avenida Amazonas 2245, \\ 38405-302 Uberlândia, MG, Brazil. \\ ${ }^{4}$ Corresponding author. E-mail: paulosouza@unipampa.edu.br
}

\begin{abstract}
The brachioradialis is an important muscle that acts in the external rotation of the forearm (supination). However, its occurrence is controversial and little studied in the order Carnivora. Thus, this study investigates the occurrence and anatomo-functional arrangement of this muscle in wild carnivorans species. Fifty-eight thoracic limbs of specimens from species of Canidae, Procyonidae, Mustelidae and Felidae were dissected. Measurements of the length of the muscle $(\mathrm{ML})$, the length of the forearm (FL), latero-medial width of the muscle (MW) and the lateral-medial diameter of the forearm (FD) were obtained to establish the ratios MW/FD and ML/FL in order to investigate the relative proportion of the muscle in relation to the forearm of each species. The brachioradialis muscle was identified in all species, although it was unilaterally or bilaterally absent in some canid individuals. The ratios demonstrated significant differences in the anatomical proportions among the families, with greater functional importance in the mustelids, procyonids, and felids because of a set of elaborate movements in the thoracic limb of representatives of these families when compared to canids.
\end{abstract}

KEY WORDS. Comparative anatomy; forelimb; myology.

Since thoracic limbs are not only used in locomotion, but also in prey capture and grooming and mating behavior, their morphology can be a good predictor of numerous ecological variables, such as the size and kind of prey, the variety of movements, the role in supporting body mass (ANDERSSON 2004a, Fabre et al. 2013a) and the habitat (DAVIs 1964, EwER et al. 1973, Taylor 1989, Polly 2007, Meachen-Samuels \& VanValkenburgh 2009, Fabre et al. 2013a, et al. 2013b, Meloro et al. 2013, Martín-Serra et al. 2014). Together with cranio-dental data, data on thoracic limbs are also used to extrapolate the predatory behavior of extinct species (IwANIUK et al. 1999, ANDERSSON \& WERDELIN 2003). Most ecomorphology studies have prioritized the osteological characteristics of the humerus, whereas the shape and other features of the radio-ulnar joint remain largely unstudied (FABRE et al. 2013a, b, 2014). Moreover, the muscular arrangement is rarely taken into account. Knowledge about muscular disposition associated with some biomechanical findings can better elucidate the function of some important bone structures that would otherwise be neglected (Julik et al. 2012). Several studies in this field have biases because of misunderstanding of the muscular topography. Thus, the addition of quantitative and qualitative data on muscular anatomy would contribute to improve the capacity to characterize forelimb morphology in the context of locomotion, grasping ability and dexterity of the species (IWANIUK et al. 2001, FABRE et al. 2013b). By homology, soft tissue information from extant species can help making well-founded or even speculative inferences about extinct species (WITMER 1995).

The musculoskeletal system forms an arrangement based on levers in which the joints act as fulcra (Hermanson 2013). The mechanical benefits of its configuration depend on the positions of the muscle attachments (relative to the fulcrum) and the usage of the load. A muscle attached close to a fulcrum is less powerful than a comparable muscle inserted at a greater distance, although the former produces its effects faster. This reflects a conflict between the requirements of speed and power (Dyce et al. 2010).

The brachioradialis muscle (formerly called the supinator longus) usually consists of a narrow muscular band situated at the flexor angle of the humerus-radius-ulna joint (Fig. 1) (Budras et al. 2012, Hermanson 2013). It is positioned between the superficial and deep layers of antebrachial fascia and adheres to the surface of the deep fascia's leaflet (Mills 2003, DycE et al. 2010, Hermanson 2013), together with the cephalic vein

2015 | Sociedade Brasileira de Zoologia | www.sbzoologia.org.br | www.scielo.br/zool All content of the journal, except where identified, is licensed under a Creative Commons attribution-type BY-NC. 


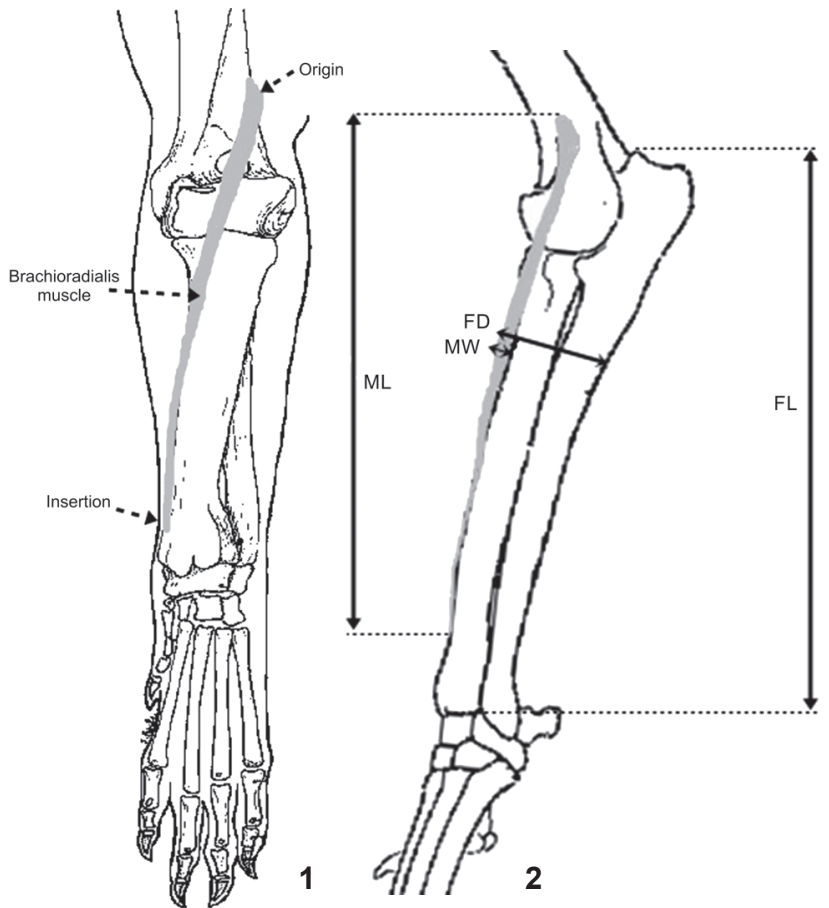

Figures 1-2. (1) Schematic representation of the basic arrangement of brachioradialis muscle in the domestic dog. (2) Schematic representations of the measurement points. ML: muscle length; FL: forearm length; MW: muscle width; FD: forearm diameter.

and the superficial branch of the radial nerve (SAINT Clair 1986, SEBASTIANi \& Fishbeck 2005), therefore being the most cranial and superficial muscle of the craniolateral group of the forearm (Bohensky 2002, Sebastiani \& Fishbeck 2005).

In domestic carnivorans, this muscle has its origin at the proximal extremity of the humeral lateral supracondylar crest, immediately proximal and superficial to the extensor carpi radialis muscle (SChwarze 1984, Mills 2003, Liebich et al. 2011, Hermanson 2013). The muscle extends cranially over the proximal part of the extensor carpi radialis muscle, crosses the forearm medially, and extends distally in the groove between the extensor carpi radialis muscle and the radius (SCHWARze 1984, Liebich et al. 2011, Hermanson 2013). It ends in the periosteum of the radius at the level of the third or fourth distal parts, by a thin aponeurosis (BoHensky 2002, Mills 2003, Budras et al. 2012, Hermanson 2013). Some authors describe its insertion into the styloid process of the radius (Leach 1976, Sebastian \& FishbeCK 2005, Liebich et al. 2011, Moore et al. 2013, Ercoli et al. 2014).

The function of the brachioradialis muscle is to perform the craniolateral rotation of the radius (supination) (BOHENSKY 2002, Sebastiani \& Fishbeck 2005, Hermanson 2013).

Supination is a movement of flipping the distal radius over the distal ulna, rotating the radius craniolaterally around its long axis (ANDERsSon 2004b). The movement starts with the contraction of forearm muscles (supinator and brachioradialis), transmitting external rotation also to the manus. Cursorial mammals often have restricted pronation-supination, whereas scansorial mammals can usually completely supinate the manus (Polly 2007). Thus, the brachioradialis functionally belongs to the group of muscles that act on the radio-ulnar joint, and is expected to be well developed only in carnivorans. In domestic ungulates, this muscle is vestigial or absent due to the reduced or lost capacity of movement between these two bones (Polly 2007, Liebich et al. 2011).

In domestic dogs, the occurrence and antimeric distribution of the brachioradialis muscle has been well documented by Wakuri \& Kano (1966), Santos Junior et al. (2002), and Pestana et al. (2009). There are no reports in the literature, as far as we know, about the occurrence of the brachioradialis muscle in wild carnivorans, although there are studies with variable contexts containing references to the presence of the muscle in Carnivora (Davis 1964, ArlamowsKa-Palider 1970, Julik et al. 2012, SÁnchez et al. 2013, Ercoli et al. 2014).

Carnivorans form a successful and functionally diverse clade, with close to 300 living species (EWER 1973, Wilson \& Mittermeier 2009, Hunter 2011). Despite this diversity, the accumulated knowledge of myological variation within the order is still incomplete (Macalister 1873a, MaCKINTOSH 1875, Windle \& Parsons 1897, Hall 1926, 1927, Howard 1973, Leach 1976, Fischer et al. 2009, Moore et al. 2013, Ercoli et al. 2014). Hence, these animals provide a good model for this study, as they represent one of the most successful cases of repeated and independent evolution of similar morphologies in a great range of ecologies (ANDERSSON 2004a, b, 2005, NowAK 2005, SATO et al. 2009, 2012, Slater et al. 2012, Fabre et al. 2013a, 2014, Samuels et al. 2013, MARTín-SERRA et al. 2014). The locomotor range of movements of carnivorans includes, to varying extents, climbing, digging, running and swimming (ANDERsSON \& Werdelin 2003). Furthermore, carnivorans species show different degrees of supination and some species cannot even use the forelimbs for grappling with or handling prey (EwER 1973, ANDERSSON \& Werdelin 2003). We hypothesized that the life style of carnivorans, including cursoriality and food procurement strategies, should be reflected in changes in brachioradialis muscle arrangement. This muscle is expected to be frequently found and to be relatively larger in species that need to rotate the forelimbs. Thereby, the aim of this study is to verify the occurrence, anatomo-functional arrangement and sexual dimorphism of the brachioradialis muscle in wild carnivoran species, thus contributing to studies in ecomorphology.

\section{MATERIAL AND METHODS}

This study was carried out with 29 carnivorans cadavers of Canidae: Cerdocyon thous (Linnaeus, 1766) (three males and six females) and Lycalopex gymnocercus (G. Fischer, 1814) (four males and one female); Mustelidae: Galictis cuja (Molina, 1782) 
(three males and two females) and Lontra longicaudis (Olfers, 1818) (one female); Procyonidae: Procyon cancrivorus (G.[Baron] Cuvier, 1798) (one male and two females) and Nasua nasua (Linnaeus, 1766) (one female); and Felidae: Leopardus geoffroyi (d'Orbigny \& Gervais, 1844) (four females) and Leopardus colocolo (Molina, 1782) (one female). These specimens were collected dead from highways in the southwest region of the state of Rio Grande do Sul (Pampa biome) between July 2012 and November 2013 (IBAMA/SISBIO authorization number 33667-1). Only adult individuals were included, based on inspection of permanent dentition.

After collection, the specimens were fixed in a formaldehyde solution (50\%) and conserved in opaque polyethylene tanks with the same solution at $10 \%$ for at least 14 days, until they were dissected. The skin and fascia of the thoracic limbs were carefully removed and the superficial intrinsic muscles identified. The brachioradialis muscle, whenever present, was dissected until its origin and insertion were exposed. Then measurements were taken (Fig. 2) of the length of the brachioradialis muscle from its origin until its insertion (ML) and the length of the forearm from the olecranon tuberosity until the radiocarpian joint (FL). Also, lateral-medial width of the brachioradialis muscle (MW) and the lateral-medial diameter of the forearm (FD) were obtained at the level of their middle thirds. The measurements were performed by a single examiner using a digital pachymeter (resolution $0.01 \mathrm{~mm}$, accuracy $\pm 0.02 \mathrm{~mm}$, ZAAS Precision Amatools ${ }^{\circledR}$ ). Thereafter, two ratios were calculated: MW/FD and ML/FL. The MW/FD ratio was calculated to reflect the relative proportion of the functional participation of the brachioradialis muscle in the forearm region of the specimens. The $\mathrm{ML} / \mathrm{FL}$ ratio represents the proportion of muscle length in relation to the forearm length and can be associated with added speed during contraction. The 29 specimens are deposited in the Laboratory of Animal Anatomy of the Universidade Federal do Pampa, Uruguaiana, RS, Brazil. The deposit numbers of the specimens analyzed are available in the appendix.

Descriptive statistical data (mean, standard deviation, variance and coefficient of variation) were calculated. The ratios were compared among species and families using analysis of variance (one-way ANOVA) and significant differences between the means were determined by using the Tukey test at $99 \%$ probability. In species with enough samples for comparison of the ratios between genders (C. thous, G. cuja and P. cancrivorus), the t-test was performed at $99 \%$ probability. These tests were executed by the BioEstat $5.3^{\circledR}$ program. Photomacrographs were taken with a Sony Cybershot DSC-TF $1{ }^{\circledR}$ camera with $16.1 \mathrm{MP}$ and the images were treated with the Photoscape ${ }^{\circledR}$ v.3.5 software.

\section{RESULTS}

Except for two specimens of L. gymnocercus, in which one male only had the muscle on the right antimere and a female only on the left, along with a female of $C$. thous that did not have the muscle in any antimere, all the other specimens (26) had the brachioradialis muscle in both antimeres. Therefore, among all 58 thoracic limbs analyzed, 54 presented the muscle (Table I).

The results of the MW/FD and ML/FL ratios grouped by family (Canidae, Mustelidae, Procyonidae and Felidae) are presented in Table II and in Figs. 3 and 4.
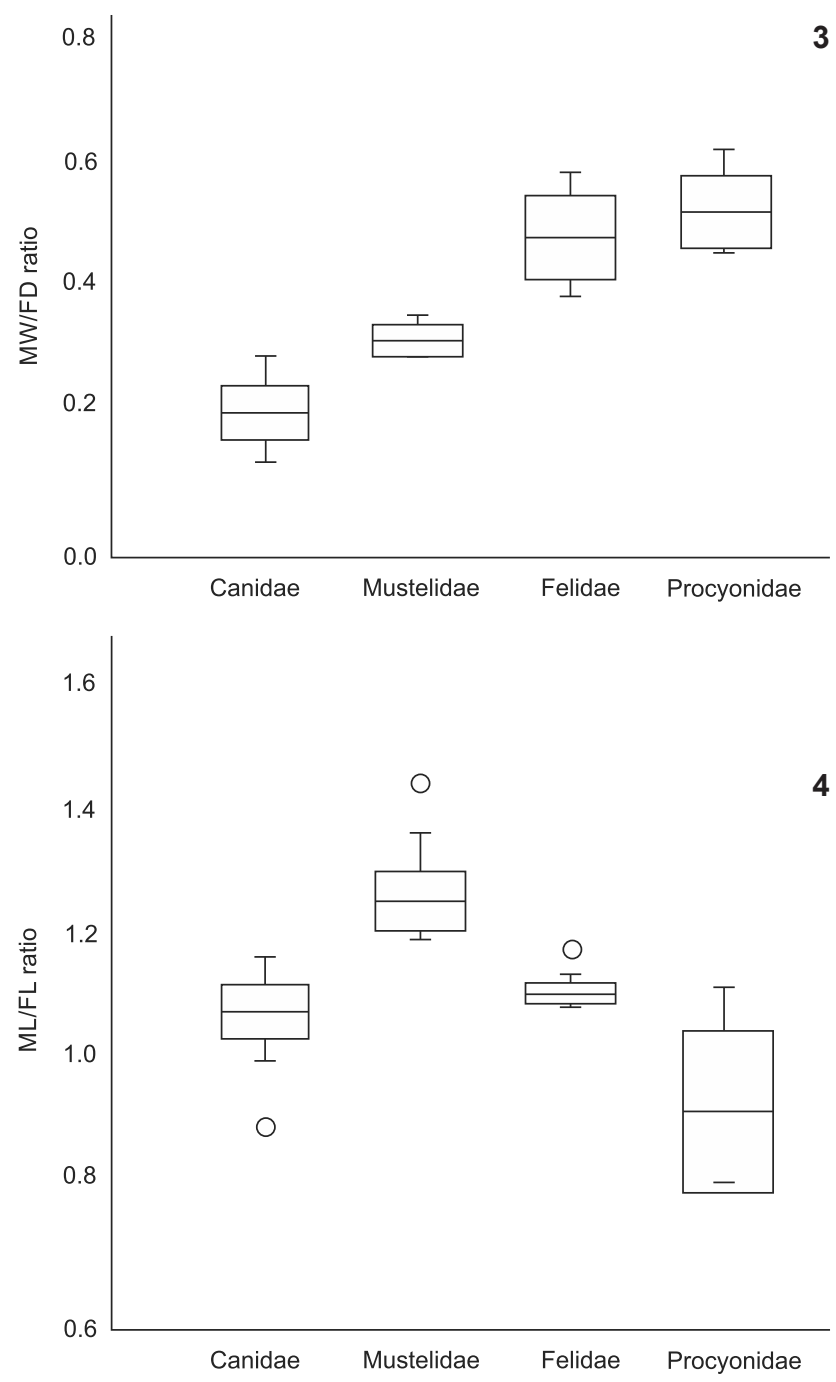

Figures 3-4. Box-plots showing the mean \pm SD of the MW/FD ratio (3) and ML/FL ratio (4) grouped by families of carnivorans analyzed.

In canids, felids and procyonids, the brachioradialis muscle originated on the lateral supracondylar crest of the humerus and its insertion was on the medial surface of the radial distal extremity (medial styloid process) in every specimen analyzed (Figs. 5-12), except one male specimen of L.gymnocercus, in which 
Table I. Means and standard deviations $(\mathrm{mm})$ of the measurements and MW/FD and ML/FL ratios obtained from the forelimbs $(n=54)$ of carnivorans specimens that presented the brachioradialis muscle.

\begin{tabular}{|c|c|c|c|c|c|c|c|c|c|c|}
\hline Family & Species & $\mathrm{n}$ & Male & Female & $\mathrm{ML}$ & MW & $\mathrm{FL}$ & FD & MW/FD Ratio & ML/FL Ratio \\
\hline Canidae & L. gymnocercus & 8 & 7 & 1 & $125.65 \pm 8.05$ & $3.46 \pm 0.98$ & $123.72 \pm 3.59$ & $22.54 \pm 1.77$ & $0.15 \pm 0.04 \mathrm{~d}$ & $1.01 \pm 0.06^{c}$ \\
\hline Canidae & C. thous & 16 & 6 & 10 & $127.43 \pm 11.7$ & $4.93 \pm 0.77$ & $117.42 \pm 11.94$ & $24.60 \pm 2.49$ & $0.20 \pm 0.03^{c d}$ & $1.08 \pm 0.04 \mathrm{bc}$ \\
\hline Mustelidae & L. longicaudis & 2 & 0 & 2 & $92.69 \pm 0.75$ & $11.66 \pm 0.24$ & $76.87 \pm 0.71$ & $40.43 \pm 0.60$ & $0.29 \pm 0.00 \mathrm{bc}$ & $1.21 \pm 0.21$ ab \\
\hline Mustelidae & G.cuja & 10 & 6 & 4 & $63.81 \pm 2.65$ & $6.83 \pm 0.53$ & $50.13 \pm 3.59$ & $22.28 \pm 1.99$ & $0.31 \pm 0.02^{b}$ & $1.27 \pm 0.07^{a}$ \\
\hline Felidae & L. geoffroyi & 8 & 0 & 8 & $112.32 \pm 3.60$ & $11.63 \pm 1.65$ & $102.39 \pm 3.38$ & $25.63 \pm 1.73$ & $0.45 \pm 0.06^{a}$ & $1.09 \pm 0.01 \mathrm{bc}$ \\
\hline Procyonidae & N. nasua & 2 & 0 & 2 & $110.94 \pm 0.49$ & $15.73 \pm 0.46$ & $100.52 \pm 0.82$ & $32.89 \pm 0.42$ & $0.48 \pm 0.02$ a & $1.11 \pm 0.01 \mathrm{bc}$ \\
\hline Procyonidae & P. cancrivorus & 6 & 2 & 4 & $112.78 \pm 4.64$ & $13.72 \pm 1.47$ & $134.54 \pm 7.88$ & $25.97 \pm 0.73$ & $0.53 \pm 0.06^{\mathrm{a}}$ & $0.84 \pm 0.05^{d}$ \\
\hline Felidae & L. colocolo & 2 & 0 & 2 & $123.59 \pm 1.31$ & $11.99 \pm 0.07$ & $107.61 \pm 1.43$ & $21.79 \pm 0.30$ & $0.55 \pm 0.04$ & $1.15 \pm 0.03 \mathrm{abc}$ \\
\hline
\end{tabular}

Values followed by different letters in the same column show statistically significant differences according to the Tukey test $(p<0.01)$. Brachioradialis muscle length (ML); brachioradialis muscle width (MW); length of the forearm (FL); diameter of the forearm (FD).

Table II. Descriptive statistics regarding the MW/FD and ML/FL ratios obtained for the thoracic limbs $(n=54)$ of carnivorans specimens grouped by families (SD) Standard deviation, (CV) Coefficient of variation.

\begin{tabular}{|c|c|c|c|c|c|c|c|c|c|c|c|c|c|c|}
\hline \multirow{2}{*}{ Family } & \multicolumn{7}{|c|}{ MW/FD ratio } & \multicolumn{7}{|c|}{$\mathrm{ML} / \mathrm{FL}$ ratio } \\
\hline & $\mathrm{n}$ & Mean & Variance & SD & CV (\%) & Minimum & Maximum & $\mathrm{n}$ & Mean & Variance & SD & CV (\%) & Minimum & Maximum \\
\hline Procyonidae & 8 & $0.51^{\mathrm{a}}$ & 0.0036 & 0.06 & 11.62 & 0.45 & 0.62 & 12 & $1.27^{\mathrm{a}}$ & 0.0050 & 0.07 & 5.62 & 1.19 & 1.44 \\
\hline Felidae & 10 & $0.47^{\mathrm{a}}$ & 0.0048 & 0.07 & 14.58 & 0.38 & 0.58 & 10 & $1.11^{\mathrm{b}}$ & 0.0008 & 0.02 & 2.48 & 1.08 & 1.17 \\
\hline Mustelidae & 12 & $0.30^{\mathrm{b}}$ & 0.0005 & 0.02 & 7.44 & 0.28 & 0.35 & 24 & $1.06^{\mathrm{b}}$ & 0.0031 & 0.05 & 5.28 & 0.88 & 1.16 \\
\hline Canidae & 24 & $0.18^{c}$ & 0.0020 & 0.45 & 24.22 & 0.11 & 0.28 & 8 & $0.91^{c}$ & 0.0171 & 0.13 & 14.38 & 0.79 & 1.11 \\
\hline
\end{tabular}

Values followed by different letters in the same column show statistically significant differences according the Tukey test $(p<0.01)$.

the right brachioradialis muscle was shortened and joined to the middle third of the extensor carpi radialis muscle. In mustelids, the muscle originated from the caudal surface of the humeral neck and caudomedially to the brachial muscle point of origin, and also was inserted in the styloid process of the radius, being very fleshy in its course. In procyonids, especially in $P$. cancrivorus, the muscular part was restricted until the middle third of the forearm, where it narrowed into a thin insertion tendon (Fig. 7). In every specimen it was the most superficial muscle in the forearm, transiting near the cephalic vein, and was innervated by branches of the radial nerve.

The t-test $(p<0.01)$ for comparison of means of the MW/ FD ratios revealed similarity between genders in $C$. thous $(\mathrm{p}=$ $0.2219), G$. cuja $(\mathrm{p}=0.7273)$ and $P$. cancrivorus $(\mathrm{p}=0.0986)$. The same test for comparison of means of the ML/FL ratios revealed similarity between genders in C. thous $(\mathrm{p}=0.4026)$ and $G$. cuja ( $\mathrm{p}=0.1743)$ and difference in P. cancrivorus $(\mathrm{p}=0.0024)$.

\section{DISCUSSION}

The presence in nearly all the specimens assessed in this study reflects the functional relevance of the brachioradialis muscle to the order Carnivora. Its occurrence is expected in species that require significant mobility in the radius-ulnar joint, especially in external rotation (supination) of the hand (paw) and forearm, which does not happen, for instance, in ungulates (Nickel et al. 1986, Liebich et al. 2011). According to SALADIN (2010), the brachioradialis muscle also acts as a synergist in the flexion of the humerus-radio-ulnar joint, but by itself it is not able to generate enough strength because its insertion is far from the fulcrum.

Only among canids were individuals identified that did not present the muscle unilaterally or bilaterally (one C. thous and two L. gymnocercus). Besides this, in one male specimen of L. gymnocercus the brachioradialis muscle was not long enough to be inserted in the radius, joining the extensor carpi radialis muscle in a clearly accessory position. The absence or presence, unilaterally or bilaterally, of the brachioradialis muscle has also been reported in C. familiaris by WAKURI \& Kano (1966), Santos Junior et al. (2002) and Pestana et al. (2009). Considered together, these three studies reveal that the brachioradialis muscle is absent in 46 to $62 \%$ of dogs, appearing unilaterally in 15 to $20 \%$ of cases. In running dogs of the greyhound breed, the muscle was not found in ten individuals dissected by WiLLiams et al. (2008). These findings corroborate the well-recognized observation that canids have lost some of the ability to supinate their manus (EwER 1973, ANDERSSON $\&$ Werdelin 2003). Therefore, in a superficial analysis considering the canids, the brachioradialis muscle seems to be more frequent in wild ones than in domestic ones, perhaps because 

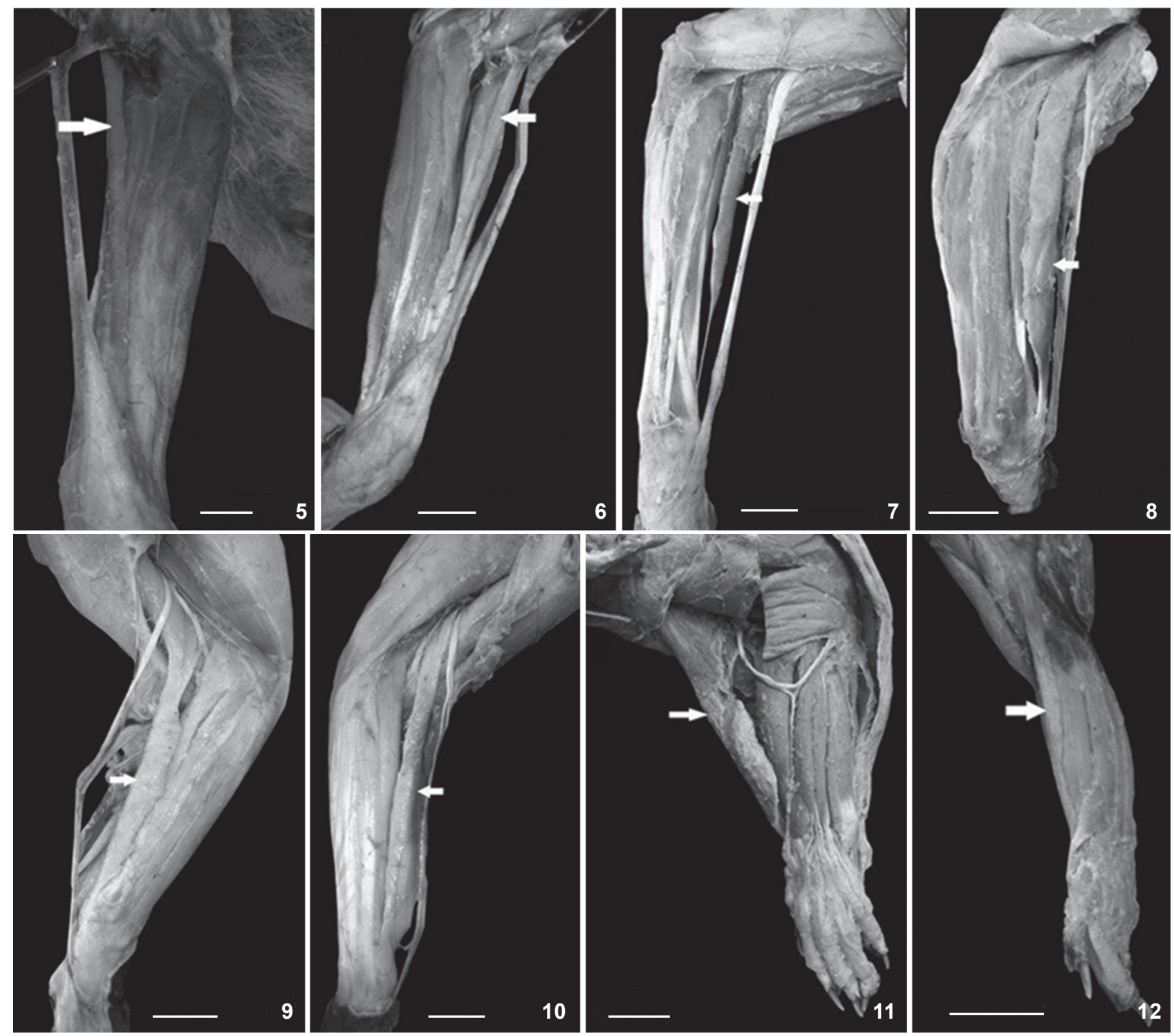

Figures 5-12. Photomacrographs showing the comparative anatomic arrangement of the brachioradialis muscle (white arrow) in the forearm region of: (5) Cerdocyon thous, right forearm; (6) Lycalopex gymnocercus, left forearm; (7) Procyon cancrivorus, right forearm; (8) Nasua nasua, right of forearm; (9) Leopardus geoffroyi, left forearm; (10) Leopardus colocolo, right forearm; (11) Lontra longicaudis, left forearm; (12) Galictis cuja, left forearm. Scale bars: $20 \mathrm{~mm}$.

the former animals retain a greater need to perform supination movements to capture prey. Nevertheless, the unilateral and even bilateral absence of this muscle in some individuals suggests that it may no longer perform a useful function and instead is a rudimentary muscle that is on its way out. The apparent absence of this muscle in greyhound dogs could reflect the increased intensity of artificial selection to eliminate a useless muscle, since it can interfere with a desirable running ability in wild canids.
After examining some specimens, W.J. Gonyea (unpubl. data) noted that the brachioradialis muscle was present in arboreal and fossorial taxa and absent in cursorial ones. In support of this hypothesis, the muscle was not identified in the cursorial canids Canis latrans (Say, 1823) $(\mathrm{n}=1)$, Urocyon cinereoargenteus (Schreber, 1775) $(\mathrm{n}=4)$ and Vulpes vulpes (Linnaeus, 1758) ( $\mathrm{n}=5$ ) (S.A. Feeney unpubl. data). The appearance of the brachioradialis muscle in almost all cursorial canids C. thous $(\mathrm{n}=8 / 9)$ and L. gymnocercus $(\mathrm{n}=5 / 5)$ analyzed 
in this study contrasts with previous observation (W.J. Gonyea, unpubl. data). Until there are more investigations, we can propose that the presence of this muscle in canids may be a characteristic shared by Neotropical species with close phylogenetic relationship rather than just a morphofunctional issue. Supporting this hypothesis, the presence of the brachioradialis muscle was also mentioned by $\mathrm{VAz}_{\mathrm{Az}}$ et al. (2011) in an adult female Atelocynus microtis (Sclater, 1883) and in an adult male C. thous. Indeed, C. thous, L. gymnocercus and A. microtis inhabit the Neotropics and have the same number of chromosomes (74) (Pessutti et al. 2001), unlike C. latrans, $U$. cinereoargenteus and $V$. vulpes (S.A. Feeney, unpubl. data).

Despite disagreement over the cursorial canids, observations of the presence of the muscle in arboreal and fossorial carnivorans are compatible with the findings of this study. In fact, the mustelids, procyonids and felids analyzed here have scansorial, arboreal and fossorial habits (Reis et al. 2010, HunTER 2011). Mustelids and procyonids in particular can display great ability to perform different kinds of movements such as grasping, swimming and food manipulation (MCCLEARN 1992, IWANIUK et al. 1999, FABRE et al. 2013b), and their lack of cursorial adaptation means that none of them have lost the ability to supinate their paws, in contrast to other carnivorans such as canids and some hyaenids (IwANIUK et al. 1999, Polly 2007, Fabre et al. 2014). Although with different purposes and small samples, some other studies have mentioned the occurrence of this muscle in species of these families, for instance in the mustelids Aonyx cinerea (Illiger, 1815) (MaCAlister 1873b), Lutra lutra (Linnaeus, 1758) (WIndLe \& PARsons 1897), Enhydra lutris (Linnaeus, 1758) (HowARd 1973), Martes pennanti (Erxleben, 1777) $(\mathrm{n}=1)$ (S.A. Feeney, unpubl. data) and G. cuja $(\mathrm{n}=3)$ (Ercoli et al. 2014); in the procyonid Procyon lotor (Linnaeus, 1758) ( $\mathrm{n}=2$ ) (S.A. Feeney, unpubl. data); and in the felids Puma concolor (Linnaeus, 1771) $(\mathrm{n}=2)$ (ConcHA et al. 2004), Acinonyx jubatus (Schreber, 1775) ( $\mathrm{n}=8)$ (Hudson et al. 2011), Leopardus pardalis (Linnaeus, 1758) ( $\mathrm{n}=1)$ (JuLIK et al. 2012) and Panthera onca (Linnaeus, 1758) ( $\mathrm{n}=2$ ) (SÁnchez et al. 2013).

The superficial location in the forearm, the proximity of the cephalic vein and innervation by branches of the radial nerve were common to all specimens analyzed, resembling the description of domestic carnivores (Sebastiani \& Fishbeck 2005, Budras et al. 2012).

The MW/FD ratio was calculated to reflect the relative proportion of its participation in the forearm region of the specimens. This way, when comparing species and/or families, those with the highest ratios should be the ones in which the brachioradialis muscle has greater relative contribution through the group of antebrachium muscles. Although calculation of physiological cross-section area (PCSA) has been used to estimate the maximum isometric force of muscles (WiLLiams et al. 2008), in this study we considered this determination to be less important since it generates an absolute value which is highly influenced by the body size of the individuals. For ex- ample, the brachioradialis of a crab-eating fox (C. thous) would exhibit both higher absolute PCSA and maximum isometric force values than the muscle in a lesser grison (G. cuja). However, the muscle is proportionally weaker in the former. Since the brachioradialis has parallel fibers, determination of the ratio between cross section widths (MW) to the forearm diameter would give a more proportional estimate of functional relevance, at least in its topographic region (forearm). In fact, the results of MW/FD ratio reflected observations from the usage of the forelimbs in each species.

The significantly lower MW/FD ratio in canids compared to the other three families used in this study can be explained by the fact that canids are essentially terrestrial and have developed a highly specialized lifestyle among carnivorans. In more cursorial taxa, the functional adaptations prioritize, among other aspects, the movements of the limbs in the sagittal plane, disfavoring supination or pronation (EwER 1973). In contrast to felids, canids have a limited ability to subdue and grapple with other animals by using their forelimbs. Instead they engage in sustained pursuit predation, an activity whose success depends on the number of animals participating in the hunt (ANDERSSON 2005). In addition, canids rarely climb or manipulate prey to a higher extent. These habits are correlated to a less functional, or even absent, brachioradialis muscle.

In the mustelids G. cuja and L. longicaudis the MW/FD ratio, significantly higher only than in the canids, comparatively reflects greater recruitment of the muscle to help in specific swimming movements and fossorial habits. At times, they also use their thoracic limbs to drag prey out of the water (ReIs et al. 2010).

The felids and procyonids of this study showed the highest MW/FD ratios, with no differences among them. The repertoire of manual movements of these two families is more complex because, besides being fast runners, they are also able to swim, climb trees and remain balanced at tall heights (ReIs et al. 2010, Hunter 2011). Undeniably, scansorial habits and grasping requires accurate three-dimensional movements, which demand morphofunctional adaptations and higher recruitment and precision in muscular contraction (EwER 1973, FABRE et al. 2013b). Procyonids even use their hands to precisely bring food into their mouths, requiring a greater capacity for supination (Paranaíba et al. 2012). Species showing well-developed grasping ability potentially have a wide range of pronation-supination movements, which can confer greater mobility to the forearm and the hand (FABRE et al. 2013b). This was the case of $P$. cancrivorus, which exhibited a high MW/FD ratio. In felids, essentially carnivores, rotation movements are even more necessary to capture, overwhelm and manipulate prey extensively (Hudson et al. 2011).

These functional correlations are coherent with those previously proposed for domestic carnivorans. According to SAINT Clair (1986), the distal muscles of the thoracic limbs are more developed in cats than in dogs to assure the greater rota- 
tion of the distal portion of the limb. The brachioradialis muscle presents a correlation not only with the forelimb usage in carnivorans. ANDERSSON (2004b) stated that manipulation and locomotion are conflicting functions, since elbow-joint morphology supports a division between grapplers (i.e., ambushers) and nongrapplers (i.e., pursuers). Joints of the former are relatively wide, while in the latter they are relatively narrow and box-like with pronounced stabilizing features. Concerning forepaw dexterity, Iwaniuk et al. (2001) considered that manus and carpal shape and myology may play a more critical role than manus proportions. According to them, behavioral observations also suggest that manus proportions correlated more closely with locomotion than non-locomotory forepaw usage.

The ML/FL ratio represents the proportion of muscle length in relation to the forearm length. This ratio was significantly higher in mustelids. Longer muscles, especially with parallel fibers (which is the case of the brachioradialis), have more sarcomeres in series, which means added speed during contraction (KaRDONG 2011). Therefore, in the mustelids one can assume that the brachioradialis muscle has a higher shortening speed than in the other families, an aspect that may be functionally important during swimming. This relatively longer length is a reflection of a more proximal level of origin in the humerus than in the other families, in other words, on the caudal surface of the humeral neck instead of the lateral supracondylar crest. Strengthening this hypothesis, in procyonids the ratio was significantly lower, because these animals have the slowest movements among the analyzed families. This shorter length was determined by the fact that its muscular part extends only until the forearm's middle third. This trait was also verified in two specimens of $P$. lotor (S.A. Feeney, unpubl. data).

From a mechanical point of view, it can be supposed that the arrangement of the mustelid brachioradialis muscle raises the power leverage, creating a low power ratio, which increases the strength and becomes important in fossorial habits. In felids, in contrast, the origin at a more distal level makes the power leverage lower, creating a higher power ratio, which increases speed, an important aspect for chasing prey. This confirms the findings of Hudson et al. (2011) for A. jubatus, that the internal architecture with long fibers of the brachioradialis muscle is an adaptation that allows the muscle to contract at high speeds and extensively rotate the radioulnar joint.

In the mustelids of the subfamily Lutrinae $A$. cinerea, $L$. lutra and E. lutris (Macalister 1873b, Windle \& Parsons 1897, Howard 1973), the brachioradialis muscle has its origin proximal to the humeral diaphysis, which also happened with $L$. longicaudis, a member of the same subfamily analyzed in this study. The origin at a proximal level could be a synapomorphy of Lutrinae. In the Lontra canadensis (Schreber, 1777), a representative species of the most basal lineage of otters, FisHER (1942) described the brachioradialis muscle as originating from the proximal region of the humerus and running to the lateral su- pracondylar crest. From an evolutionary perspective, this condition may reflect an intermediate position between the mustelids of the ferret type (Mustelinae) and lineages like otters (Lutrinae). Based on Bayesian inference methods, Koepfli et al. (2008) stated these two subfamilies diverged in the late Miocene (10 MYA) during the first burst of diversification among Mustelidae.

Among the mustelids of Mustelinae, in the five specimens of ferrets (G. cuja) dissected in this study, the muscle extended from the proximal part of the humerus to the lateral supracondylar ridge. However, in six ferrets of the same species dissected by Ercoli et al. (2014), the muscle had proximal origin in one-half (similar to the findings of this study) and in the other half the origin was restricted to the supracondylar crest. In four individuals of the species M. pennanti, the origin of the muscle occurred just proximally to the lateral humeral supracondylar ridge (S.A. Feeney, unpubl. data).

In fact, a great number of morphologic characteristics shared between the subfamilies Lutrinae and Mustelinae can be understood as favorable for both aquatic habits and locomotion in tunnels (Ercoli et al. 2014). This peculiar arrangement, elongated and wide, of the brachioradialis muscle in this family reinforces this observation. Furthermore, a more proximal origin means the levers are more equilibrated. Thus it can be assumed that the muscle also acts as an important flexor of the humerus radio-ulnar joint.

Schwarze (1984) and Dyce et al. (2010) reported that the muscle is small and almost never identified in dogs, especially in small ones. In L. gymnocercus, a canid slightly smaller than C. thous, the averages of the MW/FD and ML/FL ratios were also lower (significantly at $95 \%$ probability). However, the body size should not be a condition to predict the occurrence or functional relevance of the brachioradialis muscle in carnivorans, since small specimens such as G. cuja and felines exhibited a bilaterally well developed muscle.

In species with enough samples for comparison of the ratios between genders (C. thous, G. cuja and P. cancrivorus), only ML/FL ratio was significantly lower $(\mathrm{p}=0.024)$ in female (0.81) than male (0.92) P. cancrivorus. Though it would be desirable to study a larger number of specimens, this may reflect the need for more developed skills for pray chasing in males.

Finally, the study allowed establishing that the brachioradialis muscle occurs in individuals of the eight carnivorous species analyzed. This muscle originated on the lateral supracondylar crest of the humerus and was inserted in the medial surface of the radial distal extremity in canids, felids and procyonids, while its origin was on the caudal humeral neck in mustelids. Signs of sexual dimorphism were only detected in the relative length of the muscle in male P. cancrivorus. Overall, the mustelids, procyonids and felids have a proportionally more developed muscle than canids. As expected, these findings are consistent with the complexity and diversity of movements executed by the forelimbs of these species in the wild. 


\section{ACKNOWLEGMENTS}

We acknowledge grants received from the Scholarships for Academic Development Program (PBDA) of Universidade Federal do Pampa and from the Young Talents for Science Program awarded to the second and third authors, respectively.

\section{LITERATURE CITED}

Andersson K (2004a) Predicting carnivoran body mass from a weight-bearing joint. Journal of Zoology 262(2): 161-172. doi:10.1017/S0952836903004564

AnDERSSON K (2004b) Elbow-joint morphology as a guide to forearm function and foraging behaviour in mammalian carnivores. Zoological Journal of the Linnean Society 142 : 91-104. doi: 10.1111/j.1096-3642.2004.00129.x

Andersson K (2005) Were there pack-hunting canids in the Tertiary, and how can we know? Paleobiology 31(1): 56-72. doi:10.1666/0094-8373(2005)031<0056:WTPCIT>2.0.CO;2

Andersson K, Werdelin L (2003) The evolution of cursorial carnivores in the Tertiary: implications of elbow joint morphology. Proceeding of the Biological Society 270 (Suppl.): S163-S165. doi:10.1098/rsbl.2003.0070

ArLAmowsKA-PALIDER A (1970) Morphological Studies on the Main Branches of the Radial Nerve in Mammals. Acta Theriologica 15(2): 185-197.

Bohensky F (2002) Photo manual and dissection Guide of the Cat. New York, Square One Publishers, 167p.

Budras KD, McCarthy PH, Fricke W, Richter R, Horowitz A, Berg R (2012) Anatomia do Cão, Texto e Atlas. Barueri, Manole, 219p.

Concha I, Adaro L, Borroni C, Altamirano C (2004) Consideraciones anatómicas sobre la musculatura intrínseca del miembro torácico del puma (Puma concolor). International Journal of Morphology 22(2): 121-125. doi: 10.4067/S0717-95022004000200004

DAvis DD (1964) The giant panda: a morphological study of evolutionary mechanisms. Fieldiana: Zoology Memors 3: 1-339.

Dyce KM, SAck WO, Wensing CJG (2010) Tratado de Anatomia Veterinária. São Paulo, Elsevier, 856p.

Ercoli MD, Álvarez A, Stefanini MI, Busker F, Morales MM (2014) Muscular Anatomy of the Forelimbs of the Lesser Grison (Galictis cuja), and a Functional and Phylogenetic Overview of Mustelidae and Other Caniformia. Journal of Mammalian Evolution 22(1): 57-91. doi: 10.1007/s10914-014-9257-6

EwER RF (1973) The Carnivores. New York, Cornell University Press, 494p.

Fabre AC, Cornette R, Peigné S, Goswami A (2013a) Influence of body mass on the shape of forelimb in musteloid carnivorans. Biological Journal of the Linnean Society 110: 91-103. doi: 10.1111/bij.12103

Fabre AC, Cornette R, Slater G, Argot C, Peigné S, Goswami A, Pouydebat E (2013b) Getting a grip on the evolution of grasping in musteloid carnivorans: a three-dimensional analysis of forelimb shape. Journal of Evolutionary Biology 26: 1521-1535. doi: 10.1111/jeb.12161

Fabre AC, Goswami A, Peigné S, Cornette R (2014) Morphological integration in the forelimb of musteloid carnivorans. Journal of Anatomy 225: 19-30. doi: 10.1111/joa.12194

FisHer EM (1942) The Osteology and Myology of the California River Otter. Stanford, Stanford University Press, 66p.

Fisher RE, Adrian B, Barton M, Holmgren J, Tang SY (2009) The phylogeny of the red panda (Ailurus fulgens): evidence from the forelimb. Journal of Anatomy 215 (6): 611-635. doi:10.1111/j.1469-7580.2009.01156.x

HaLl ER (1926). The muscular anatomy of three mustelid mammals, Mephitis, Spilogale, and Martes. University of California Publications in Zoology 30(2): 7-39.

HaLl ER (1927) The muscular anatomy of the American badger (Taxidea taxus). University of California Publications in Zoology 30(8): 205-219.

Hermanson JW (2013) The Muscular System, p. 185-280. In: Evans HE, Delahunta A (Eds) Miller's Anatomy of the Dog. Missouri, Elsevier, 872p.

Howard LD (1973) Muscular anatomy of the fore-limb of the sea otter (Enhydra lutris). Proceedings of the California Academia of Science 39(4): 411-500.

Hudson PE, Corr SA, Payne-Davis RC, Clancy SN, Lane E, Wilson AM (2011) Functional anatomy of the cheetah (Acinonyx jubatus) forelimb. Journal of Anatomy 218(4): 375-385. doi: 10.1111/j.1469-7580.2011.01344.x

HunTER L (2011) Carnivores of the world. Princeton, Princeton University Press, 240p.

Iwaniuk AN, Pellis SM, Whishaw IQ (1999) The relationship between forelimb morphology and behaviour in North American carnivores (Carnivora). Canadian Journal of Zoology 77(7): 1064-1074. doi: 10.1139/z99-082

Iwaniuk AN, Pellis SM, Whishaw IQ (2001) Are long digits correlated with high forepaw dexterity? A comparative test in terrestrial carnivores (Carnivora). Canadian Journal of Zoology 79(5): 900-906. doi: 10.1139/z01-058

Julik E, Zack S, Adrian B, Maredia S, Parsa A, Poole M, Starbuck A, FIsHER RE (2012) Functional Anatomy of the Forelimb Muscles of the Ocelot (Leopardus pardalis). Journal of Mammalian Evolution 19(4): 277-304. doi:10.1007/s10914-012-9191-4

KARDONG KV (2011) Vertebrados: anatomia comparada, função e evolução. São Paulo, Roca, 913p.

Koepfli KP, Deere KA, Slater GJ, Begg C, Begg K, Grassman L, Lucherini M, Veron G, Wayne RK (2008) Multigene phylogeny of the Mustelidae: resolving relationships, tempo and biogeographic history of a mammalian adaptive radiation. BMC Biology 6(10): 122. doi: 10.1186/1741-7007-6-10

LEACH D (1976) The forelimb musculature of marten (Martes americana Turton) and fisher (Martes pennanti Erxleben). Canadian Journal of Zoology 55(1): 31-41. doi:10.1139/z77-00

Liebich HG, MaierL J, König HE (2011) Membros Torácicos ou Anteriores (Membra Thoracica), p. 165-234. In: KöNIG HE, 
Liebich HG (Eds) Anatomia dos Animais Domésticos: Texto e Atlas Colorido. Porto Alegre, Artmed, 787p.

Macalister A (1873a) The muscular anatomy of the civet and tayra. Proceedings of the Royal Irish Academy Academy Series 2: 506-513.

Macalister A (1873b) On the anatomy of Aonyx. Proceedings of the Royal Irish Academy Series 2: 539-547.

Mackintosh BA (1875) Notes on the myology of the coati mondth (Nasua narica and N. fusca) and common marten (Martes foina). Proceedings of the Royal lrish Academy Series 2: 48-55.

Martín-Serra A, Figueirido B, Palmqvist P (2014) A Three-Dimensional Analysis of Morphological Evolution and Locomotor Performance of the Carnivoran Forelimb. PLoS ONE 9: e85574. doi:10.1371/journal.pone.0085574

MCCleARn D (1992) Locomotion, Posture, and feeding behavior of kinkajous, coatis, and raccoons. Journal of Mammalogy 73 (2): 245-261.

Meachen-Samuels JA, Van-Valkenburgh B (2009) Forelimb indicators of prey-size preference in the Felidae. Journal of Morphology 270 (6): 729-744. doi: 10.1002/jmor.10712

Meloro C, Elton C, Louys J, Bishop LC, Ditchfield P (2013) Cats in the forest: predicting habitat adaptations from humerus morphometry in extant and fossil Felidae (Carnivora). Paleobiology 39(3): 323-244. doi:10.1666/12001

Mills P (2003) Comparative Animal Anatomy. Queensland, Gatton Desktop Publishing, 316p.

Moore AL, Budny JE, Russel AP, Butcher MT (2013) Architectural specialization of the intrinsic thoracic limb musculature of the American badger (Taxidea taxus). Journal of Morphology 274(1): 35-48. doi: 10.1002/jmor.20074

Nickel R, Schummer A, Seiferle E, Frewein J, Wilkens H, Wille K (1986) The Locomotor System of Domestic Mammals. Berlin, Verlag Paul Parey, 515p.

NowAK RM (2005) Walker's Carnivores of the World. Baltimore, The Johns Hopkins University Press, 328p.

Paranaiba Jf, Helrigle C, Araújo EG, Pereira KF (2012) Aspectos morfológicos da mão e pé de Procyon cancrivorus. Natureza On line 10 (4): 165-169. Available online at: http:// www.naturezaonline.com.br/natureza/conteudo/pdf/ 03_ParanaibaJFetal_165_169.pdf. [Accessed: 31 July 2014]

Pessutti C, Santiago MEB, Oliveira LTF (2001) Order Carnivora, Family Canidae (Dogs, foxes and maned wolves), p. 279290. In: Fowler ME, CubAs ZS (Eds) Biology, Medicine and Surgery of South American Wild Animals. Ames, Iowa State University Press, 550p.

Pestana FM, Silva BX, Chagas MA, Babinski MA, Abidu-Figueiredo M (2009) Distribuição antimérica do músculo braquiorradial em cães sem raça definida. Revista de Ciências da Vida 29(1): 55-59.

PolLy PD (2007) Limbs in mammalian evolution, p. 245-268. In: Hall BK (Ed.) Fins into Limbs: Evolution, Development, and Transformation. Chicago, University of Chicago Press, 344p.
Reis NR, Peracchi AL, Fregonezi MN, Rossaneis BK (2010) Mamíferos do Brasil: guia de identificação. Rio de Janeiro, Technical Books, 560p.

SaInt Clair LE (1986) Músculos do carnívoro, p. 1416-1444. In: Getty R (Ed.) Anatomia dos Animais Domésticos. Rio de Janeiro, Guanabara Koogan, 2048p.

SALAdIN KS (2010) Anatomy and Physiology: The Unity of Form and Function. New York, McGraw Hill, 1248p.

Samuels JX, Meachen JA, Sakai SA (2013) Postcranial morphology and the locomotor habits of living and extinct carnivorans. Journal of Morphology 274(2): 121-146. doi:10.1002/ jmor. 20077

Sánchez HL, Silva lB, Rafasquino ME, Mateo AG, Zuccolilli GO, Portiansky EL, Alonso CR (2013) Anatomical study of the forearm and hand nerves of the domestic cat (Felis catus), puma (Puma concolor) and jaguar (Panthera onca). Anatomia Histologia Embryologia 42 (2): 99-104. doi: 10.1111/ j.1439-0264.2012.01170.x

Santos Junior I, Rodrigues CA, Campos A, Santos D (2002) Presença do músculo braquiorradial em cães. Bioscience Journal 18(1): 79-83.

Sato JJ, Wolsan M, Minami S, Hosoda T, Sinaga MH, Hiyama K, Yamaguchi Y, SuzuKi H (2009) Deciphering and dating the red panda's ancestry and early adaptive radiation of Musteloidea. Molecular Phylogenetics and Evolution 53(3): 907-922. doi:10.1016/j.ympev.2009.08.019

Sato JJ, Wolsan M, Prevosti FJF, D’Elía G, Begg C, Begg K, Hosoda T, CAmpbell KL, SuzuKi H (2012) Evolutionary and biogeographic history of Weasellike carnivorans (Musteloidea). Molecular Phylogenetics and Evolution 63(3): 745-757. doi:10.1016/ j.ympev.2012.02.025

Schwarze E (1984) Compendio de Anatomia Veterinaria. Zaragoza, Editora Acribia, 318p.

Slater GJ, Harmon LJ, Alfaro ME (2012) Integrating fossils with molecular phylogenies improves inference of trait evolution. Evolution 66(12): 3931-3944. doi:10.1111/j.15585646.2012.01723.x

Sebastiani AM, Fishbeck DW (2005) Mammalian anatomy: the cat. Colorado, Morton Publishing Company, 184p.

TAYLOR ME (1989) Locomotor adaptations by carnivores, p. 382409. In: Gittleman JL (Ed.) Carnivore Behavior, Ecology, and Evolution. Cornell, Comstosck Publiching Associates, 620 p.

Vaz MGR, Lima AR, Souza ACb, Pereira LC, Branco E (2011) Estudo morfológico dos músculos do antebraço de cachorrodo-mato-de-orelhas-curtas (Atelocynus microtis) e cachorrodo-mato (Cerdocyon thous). Biotemas 24(4): 121-127. doi:10.5007/2175-7925.2011v24n4p121

WAKURI H, KANO Y (1966) Anatomical studies on the brachioradial muscle in dogs. Acta Anatomica Nipponica 41: 222-231.

Williams SB, Wilson AM, Rhodes L, Andrews J, Payne RC (2008) Functional anatomy and muscle moment arms of the thoracic limb of an elite sprinting athlete: the racing 
greyhound (Canis familiaris). Journal of Anatomy 213(4): 361-372. doi: 10.1111/j.1469-7580.2008.00962.x

WiLson DE, MitTermeier RA (2009) Handbook of the Mammals of the World. Barcelona, Lynx Edicions, vol. 1, 727p.

WindLE BCA, PARSONS FG (1897) On the myology of the terrestrial

Carnivora. Part I: muscles of the head, neck, and fore-limb.
Proceedings of Zoological Society of London 65: 370-409. WitMER LM (1995) The extant phylogenetic bracket and the importance of reconstructing soft tissues in fossils, p. 1933. In: Thomason JJ (Ed.) Functional morphology in vertebrate paleontology. Cambridge, Cambridge University Press, 277p.

Appendix. The specimens analyzed are deposited in the Laboratory of Animal Anatomy of Universidade Federal do Pampa, Uruguaiana, RS, Brazil, with the following numbers:

Cerdocyon thous: 5139, 5144, 5267, 5273, 5275, 5717, 8503, 8504, 8505

Lycalopex gymnocercus: 5134, 5261, 5269, 5274, 5603

Procyon cancrivorus: $5136,5268,8517$

Galictis cuja: 5142, 5146, 5599, 5714, 5720

Leopardus geoffroyi: 5138, 5145, 5147, 5150

Nasua nasua: 8527

Lontra longicaudis: 8507

Leopardus colocolo: 5137

Submitted: 11 August 2014

Received in revised form: 25 December 2014

Accepted: 5 February 2015

Editorial responsibility: Carolina Arruda Freire 